\title{
Dissipation kinetics and leaching of cyazofamid fungicide in texturally different agricultural soils
}

\author{
N. Singh $\cdot$ S. Tandon
}

Received: 26 May 2012/Revised: 29 November 2013/ Accepted: 28 April 2014/Published online: 20 May 2014

(C) Islamic Azad University (IAU) 2014

\begin{abstract}
Dissipation and leaching studies of cyazofamid in two texturally different soils of Tarai region of India at two fortification levels (100 and $200 \mathrm{~g}$ a.i. $\mathrm{ha}^{-1}$ ) were carried out for monitoring residual toxicity and groundwater contamination. Soil was extracted with acetone : methanol $(5: 1 \mathrm{v} / \mathrm{v})$ followed by cleanup with florisil SPE. Separation was achieved by RP-HPLC on a Discovery ${ }^{\circledR}$ C-18 column using mobile phase acetonitrile: water (60:40 $\mathrm{v} / \mathrm{v}$ ) and detection at $279 \mathrm{~nm}$. Degradation pattern indicated correspondence to monophasic first-order kinetics in soils with half-life values ranging from 4.3 to 4.95 days. The degradation rate was slight different in both types of soils. Persistence was higher in sandy loam compared to silty clay loam soil. Linearity, $R^{2}$ of calibration curve, instrument limit of detection/quantitation (LOD/LOQ) was evaluated. Good linearity $\left(R^{2}=0.99\right)$ of the calibration curves for quantification was obtained over the dynamic range of $0.1-10.0 \mu \mathrm{g} \mathrm{mL}^{-1}$, and percent relative standard deviation was $1.72 \%$. Leaching experiment showed that cyazofamid could not leached beyond $15 \mathrm{~cm}$ of soil depth. Maximum concentration was at 5-10 and $10-15 \mathrm{~cm}$ soil depth. Average recoveries from soils fortified at $0.5-5.0 \mu \mathrm{g} \mathrm{g}^{-1}$ ranged from 78 to $86 \%$. Instrument LOD values were $0.01 \mu \mathrm{g} \mathrm{mL}^{-1}$, and method LOQ values were $0.05 \mu \mathrm{g} \mathrm{g}^{-1}$. A fast, easy and efficient method with acceptable performance was achieved. Results showed that cyazofamid has a short life in soils and low potential to leach down under heavy rainfall conditions. Results confirm that cyazofamid would not build up in the
\end{abstract}

N. Singh $\cdot$ S. Tandon $(\bowtie)$

Division of Agricultural Chemicals, Department of Chemistry,

G. B. Pant University of Agriculture \& Technology, Pantnagar

263 145, Uttarakhand, India

e-mail: shishir_tandon2000@yahoo.co.in environment and have less possibility of groundwater contamination.

Keywords Cyazofamid $\cdot$ RP-HPLC $\cdot$ Half-life · Leaching $\cdot$ Dissipation $\cdot$ Kinetics

\section{Introduction}

Indiscriminate and unjudicious use of pesticides with high residual activity and potential mobility has caused lots of serious environmental problems which were not earlier anticipated as soil and air contamination and pollution. Soil, an important component of the environment, acts as a sink for the pesticides used in agriculture. The buildup of pesticide residues in soil is adversely affecting the soil health as well as polluting the subsoil water (Arora 2006). Presence of pesticide residues in soil may cause detrimental effect on human and animal health and sometime acts as a source of contamination for succeeding crops. From soil, these residues can reach water bodies by leaching and runoff, and as they are inherently toxic molecules on reaching water bodies, they start adversely affecting aquatic environment and non-targeted organism. Presence of pesticides in groundwater is extremely hazardous as groundwater is major source of drinking water.

Cyazofamid, [4-chloro-2-cyano- $N, N$-dimethyl-5- $p$-tolylimidazole-1-sulfonamide] a member of phenylimidazole fungicide, has broad spectrum activity against oomycetes and plasmodiophoromycetes with different site of action and specifically active for the control of late blight on potatoes and tomatoes, and downy mildew on grapevine, cucumbers and melons worldwide (Ohshima et al. 2004; Mitani 2001). It has novel and unique mode of action as it kills oomycetes fungi by respiration inhibition. It disrupts 
the energy supply by blocking the electron transfer at the Qi (ubiquinone reducing site) center of complex III of the enzyme cytochrome bc1 complex in mitochondria. It affects all stages in the life cycle of $P$. infestans including germination of cytospores, formation of oospores, zoospores motility and mycelia growth (Mitani et al. 2001a, b, 2002; Yamaguchi and Fujimura 2005).

Work on the analysis on cyazofamid from soil/water/air is very limited, and no work had been reported from Indian soils and conditions. Some literature have reported work on the analysis of cyazofamid pure technical (Xu et al. 2009), photolysis (Zong et al. 2009), soil (Tandon and Singh 2012; Huang et al. 2005), water and air (Fischer et al. 2003), crops (Matsubayashi et al. 1995; Choi et al. 2007; Heimstra and Kok 2007; Lacina et al. 2010) multiresidue in fruits and vegetables (Rial et al. 2003; Pihlstrom et al. 2007; González-Rodríguez et al. 2009; Tseng et al. 2009; European food safety Authority 2012; Lee et al. 2012) animal tissue (Pang et al. 2006a) and food grain (Pang et al. 2006b; Pizzutti et al. 2009).

Pesticide persistence and mobility are largely influenced by the properties of the pesticides. In soil, it is subjected to adsorption, plant uptake, weather condition, application method, movement and degradation depending on the simultaneous influence of physical, chemical and biological processes. The behavior of pesticides in soil, therefore, depends on the characteristics and overall function of the ecosystem as well as physicochemical properties of active ingredients and of its formulated products (Flury 1996; Kerle et al. 2007). In addition to adsorption and biodegradation, it has been recently shown that reduced sulfur species and dissolved organic matter present in soil/sediment are capable of promoting the in situ transformation of otherwise recalcitrant pesticides (Zeng et al. 2011, 2012).

Pesticide leaching or transport through the unsaturated/ saturated zone is a function of chemical and soil characteristics, application and water recharge rate (Hancock et al. 2008). Leaching of pesticides is predicted to be greatest for shallow soils and for persistent compounds with low sorptivity (Webb et al. 2008). Estimation of fungicide residues is very useful to determine the persistence and its effect on crop and the quality of food and feed. The information of degradation rate and leaching behavior in soil helps to access and predict the residual toxicity and groundwater pollution, as a whole, environmental behavior of pesticide. Recommendations for the use of a pesticide on a crop cannot be made until studies of its persistence and leaching have been carried out. Information on degradation rate and downward movement also helps to assess and predict the environmental behavior of the pesticide (Laskowski et al. 1983).

The work on persistence and leaching behavior of cyazofamid has not been reported in Indian soils and subtropical conditions. The registration of cyazofamid is proposed for use is under consideration by Central Insecticide Board, DPPQS, India. Thus, study pertaining to its persistence and leaching behavior in soil is essential to get an idea about its extent of residue, thereby predicting the risk of residual toxicity and groundwater pollution. The focus of these studies has been to measure the rate of degradation of the active ingredient as well as to assess the potential for leaching of this compound into the soil. Therefore, a sensitive analytical method capable of estimation of its microquantities in soil is required. Thus, the present studies were undertaken to find the persistence and leaching behavior of cyazofamid in different soils of Tarai region of Uttarakhand, India.

\section{Materials and methods}

\section{Instruments}

Water's model Gradient HPLC system with varying wavelength equipped with UV detector, 7725i rheodyne injector $20-\mu \mathrm{L}$ loop and HP 3395 series integrator recorder, P.C. controlled double beam (PMT detector) UV-Visible spectrophotometer Model 2101 (Systronics, India), rotavapor (Buchii, Switzerland) and SPE miniplastic florisil columns $(6.0 \times 0.75 \mathrm{~cm}$ id $)$ packed with $500 \mathrm{mg}$ florisil packing material (Varian/Supelco, USA) were used. For estimation and separation Discovery ${ }^{\circledR}$ C-18, $5 \mu \mathrm{m}$, $(15 \mathrm{~cm} \times 4.6 \mathrm{~mm}$, stainless steel) column (SigmaAldrich) was used for analysis.

\section{Chemicals and glasswares}

Analytical grade (AR) cyazofamid of $99.3 \%$ pure was obtained from courtesy M/s Ishihara Sangyo Kaisha (ISK) Biosciences Corporation, Japan. The structure and some physicochemical properties of cyazofamid are given in Table 1. All the glasswares used were of Corning, Pyrex or Borosil make. Solvents used were of AR or HPLC grade. Triple distilled water was prepared in the laboratory by double distillation of single metal distilled water in all quartz double distillation assembly.

\section{Sampling}

Soils samples representing the major soil type of Tarai region of Uttarakhand were collected at different depths viz $0-15,15-30,30-45$ and $45-60 \mathrm{~cm}$ from five randomly selected spots with the help of tube auger from the N. E. Borlaug Crop Research Centre, Govind Ballabh Pant University of Agriculture \& Technology, Pantnagar, India. Surface soil of $0-15 \mathrm{~cm}$ was used for persistence study, 
Table 1 Structure and physicochemical properties of cyazofamid

\begin{tabular}{|c|c|}
\hline \multicolumn{2}{|l|}{ Structure } \\
\hline $\begin{array}{l}\text { Molecular } \\
\text { formula }\end{array}$ & $\mathrm{C}_{13} \mathrm{H}_{13} \mathrm{ClN}_{4} \mathrm{O}_{2} \mathrm{~S}$ \\
\hline $\begin{array}{l}\text { Molecular } \\
\text { mass }\end{array}$ & 324.8 \\
\hline Melting point & $152.7{ }^{\circ} \mathrm{C}(99.1 \%)$ \\
\hline Appearance & White, odorless solid powder (99.1\%) \\
\hline \multirow{3}{*}{$\begin{array}{l}\text { Solubility in } \\
\text { water@ } \\
20{ }^{\circ} \mathrm{C}(\mathrm{mg} \\
\left.\mathrm{L}^{-1}\right)\end{array}$} & 0.121 \\
\hline & 0.107 \\
\hline & 0.109 \\
\hline $\begin{array}{l}\text { Partition } \\
\text { coefficient } \\
\text { (log Pow) }\end{array}$ & 3.2 at $25^{\circ} \mathrm{C}$ \\
\hline $\begin{array}{l}\text { Octanol-water } \\
\text { partition } \\
\text { coefficient }\end{array}$ & $1.58 \times 10^{3}$ at $\mathrm{pH} 7 \& 20^{\circ} \mathrm{C}$ \\
\hline $\begin{array}{l}\text { Dissociation } \\
\text { constant } \\
(\mathrm{p} K \mathrm{a})\end{array}$ & $\begin{array}{l}\text { Does not dissociate in water. No } \mathrm{p} K \mathrm{a} \text { in the } \mathrm{pH} \\
\text { range of } 2-12\end{array}$ \\
\hline \multirow{4}{*}{$\begin{array}{l}\text { Adsorption/ } \\
\text { desorption } \\
\text { (Kd and Koc } \\
\text { in } \mathrm{L} \mathrm{Kg}^{-1} \text { ) }\end{array}$} & $\begin{array}{l}\text { Loamy sand (Ohio): } \mathrm{Kd}=9.99 / 6.96 \text { and } \\
\mathrm{Koc}=1,524 / 1,062\end{array}$ \\
\hline & $\begin{array}{l}\text { Sandy loam }(\mathrm{UK}): \mathrm{Kd}=43.31 / 87.00 \text { and } \\
\text { Koc }=1,444 / 2,900\end{array}$ \\
\hline & $\begin{array}{l}\text { Sandy loam }(\mathrm{UK}): \mathrm{Kd}=14.11 / 13.49 \text { and } \\
\text { Koc }=1,176 / 1,124\end{array}$ \\
\hline & $\begin{array}{l}\text { Sand (Germany): Kd }=5.14 / 4.14 \text { and } \\
\text { Koc }=815 / 657\end{array}$ \\
\hline
\end{tabular}

USEPA (2004)

and soil from different depths was used in leaching study. To bring the uniformity and destroy unwanted weed seeds present in the soil, it was moistened to field capacity for a period of 7 days in plastic bucket. After incubation, the soil was air-dried, powdered, passed through 2-mm sieve and stored in polythene bags in deep freezer till analysis. Soil were analyzed for its physicochemical properties like $\mathrm{pH}$, $\mathrm{CEC}$, organic carbon, $\mathrm{CaCO}_{3}$ percent, moisture content, water holding capacity and proportion of sand silt and clay fraction by standard analytical procedure (Jackson 1973).

\section{Persistence Studies}

Shade air-dried powdered $2 \mathrm{~kg}$ of $2 \mathrm{~mm}$ size soil samples was taken from both the soils in glass trays. Three treatments consisting of control and cyazofamid were applied.
Table 2 Metrological data for the month of experiment

\begin{tabular}{llllll}
\hline Month & Week & \multicolumn{2}{c}{ Temperature $\left({ }^{\circ} \mathrm{C}\right)$} & \multicolumn{3}{c}{ Relative humidity $(\%)$} \\
\cline { 4 - 6 } & & Max. & Min. & Max. & Min. \\
\hline February, 2010 & 3 & 25.3 & 10.1 & 88 & 47 \\
& 4 & 24.6 & 11.8 & 86 & 48 \\
March, 2010 & 1 & 30.6 & 12.5 & 87 & 42 \\
& 2 & 34.2 & 13.2 & 86 & 36 \\
April, 2010 & 3 & 30.9 & 16.2 & 88 & 33 \\
\hline
\end{tabular}

Both soils were fortified and mixed thoroughly with 20 and $40 \mathrm{~mL}$ of $5 \mu \mathrm{g} \mathrm{g}^{-1}$ cyazofamid solution equivalent to recommended $\left[100 \mathrm{~g}\right.$ a.i. $\left.\mathrm{ha}^{-1}\left(\mathrm{~T}_{1}\right)\right]$ and double recommended [200 g a.i. ha $\left.{ }^{-1}\left(\mathrm{~T}_{2}\right)\right]$ application doses of fungicide, respectively. Each treatment was replicated thrice, and $15 \%$ soil moisture was maintained throughout the experiment. The metrological data during the persistence studies is given in Table 2. Representative samples of $50 \mathrm{~g}$ were drawn from fortified soils by randomized sampling in triplicate from each treatment at regular intervals $(0,1,3$, $5,7,10,15$ and 30 days after treatment) and were processed for estimation of cyazofamid residues as given below. Control samples for both soils were also kept with similar moisture but without treatment or without fortification of cyazofamid.

The experiment was laid in completely randomized block design (CRD) fashion, and all the treatments were replicated thrice. Data were subjected to analysis to determine standard deviation among the replicates (Gomez and Gomez 1984).

\section{Leaching studies}

The leaching studies were performed at ambient temperature $25 \pm 2{ }^{\circ} \mathrm{C}$ in columns made from polyvinyl chloride (PVC) of $60 \mathrm{~cm}$ length with $10 \mathrm{~cm}$ i.d. One end of PVC columns were covered with double layer of muslin cloth and then sequentially filled the soil from the bottom and packed with $7.2 \mathrm{~kg}(2.0 \mathrm{~kg}$ for $45-60 \mathrm{~cm}, 1.9 \mathrm{~kg}$ for $30-45 \mathrm{~cm}, 1.7 \mathrm{~kg}$ for $15-30 \mathrm{~cm}$ and $1.5 \mathrm{~kg}$ for $0-15 \mathrm{~cm}$ depth) sandy loam and $7.0 \mathrm{~kg}$ ( $1.9 \mathrm{~kg}$ for $45-60 \mathrm{~cm}, 1.8 \mathrm{~kg}$ for $30-45 \mathrm{~cm}, 1.7 \mathrm{~kg}$ for $15-30 \mathrm{~cm}$ and $1.6 \mathrm{~kg}$ for 0-15 cm depth) silty clay loam soils with control columns for reference. For maintaining similar column length of different soil layers, different soil weights were used because of difference in the bulk density of both soils. The upper part of the each column was uniformly covered with glass wool to assist uniform dispersion of the water across the column surface and to minimize the surface disturbance. Columns were saturated overnight by flowing water 
from above and keeping them dipped in water in a bucket, excess water was drained out by 1- day drainage cycle, and columns were covered with aluminum foil to prevent loss of water by evaporation. PVC funnel was attached to the bottom of each column to collect the leachates into 500-mL flasks.

For monitoring vertical movement and leaching loss of cyazofamid, the $T_{1}\left(0.1 \mathrm{~kg} \mathrm{ha}^{-1}\right)$ and $\mathrm{T}_{2}\left(0.2 \mathrm{~kg} \mathrm{ha}^{-1}\right)$ treatments were applied to surface of column. The fungicide was allowed to equilibrate with the soil for $2 \mathrm{~h}$ before the leaching process was initiated. The addition of water was divided into 24 hourly applications of $120 \mathrm{~mL}$ for five days (equivalent to $1,400-\mathrm{mm}$ annual rain fall) so that infiltration rate of soil does not exceed the annual rainfall limit. Soil columns receiving respective amount of water only served as control. After five days, when addition of water was completed, the soil columns were allowed to drain for $24 \mathrm{~h}$ and were cut into two halves and the soils was cut into $5-\mathrm{cm}$ segments, pooled, air-dried and processed for analyzing cyazofamid residue as described below. Water eluted daily from the columns was collected and processed for fungicide quantity. The experiment was laid in CRD fashion, and all the treatments were replicated thrice. Data were subjected to analysis to determine standard deviation among the replicates.

\section{Recovery}

Shade-dried powdered soil was spiked with $0.5,2.0$ and $5.0 \mu \mathrm{g} \mathrm{g}^{-1}$ of cyazofamid. Soil was maintained at 15 percent moisture. All the experiment was done in triplicate. The soil was extracted, cleaned up and analyzed following the procedure as described below.

\section{Extraction procedures}

Extraction was done according to method developed by Tandon and Singh (2012). Soil sample (50 g) was mixed with $100 \mathrm{~mL}$ of acetone: methanol $(5: 1 \mathrm{v} / \mathrm{v})$ in conical flask, and the content was shaken for $30 \mathrm{~min}$ on a rotatory shaker, centrifuged and filtered. The procedure was repeated twice with $50-\mathrm{mL}$ of solvent system. The clear supernatant obtained was pooled into a $250-\mathrm{mL}$ conical flask. The combined organic layer was dried over anhydrous sodium sulfate, and the content was filter through Whatman No. 1 filter paper. The residue on funnel was rinsed twice with $5 \mathrm{~mL}$ of solvent. The extract was evaporated at $45 \pm 1{ }^{\circ} \mathrm{C}$ to dryness under reduced pressure with help of Buchii Flash Evaporator. Residues were dissolved in $1 \mathrm{~mL}$ of dichloromethane and subjected to cleanup.

The cleanup was done using florisil SPE cartridge which was prewashed with $5 \mathrm{~mL}$ of dichloromethane. One milliliter sample was loaded on florisil cartridge, and sample was eluted with $1.5 \mathrm{~mL}$ dichloromethane. The eluted sample was dried under the stream of nitrogen and redissolved in $1 \mathrm{~mL}$ acetonitrile and used for HPLC analysis. The samples were filtered through $0.22-\mu \mathrm{m}$ PTFE disk filter prior to HPLC.

Chromatographic conditions and calibration curve

The $\lambda$ max of cyazofamid was obtained on UV-VIS spectrophotometer using following conditions: bandwidth $0.5 \mathrm{~mm}$, range $200-400 \mathrm{~nm}$, mode scan, scan speed: slow. The operating chromatographic conditions for the RPHPLC were Discovery ${ }^{\circledR}$ C-18 column $(150 \times 4.6 \mathrm{~mm}$ i.d. $\times 5.0 \mu \mathrm{m}$ particle size). The column was maintained at room temperature of $27 \pm 1{ }^{\circ} \mathrm{C}$. The operating parameters were mobile phase acetonitrile: water (60:40, $\mathrm{v} / \mathrm{v})$ with isocratic mode at a flow rate of $1 \mathrm{~mL} \mathrm{~min}^{-1}$ and UV detection of $279 \mathrm{~nm}$. The sample injection volume was $20 \mu \mathrm{L}$.

A calibration curve was plotted between different concentration of cyazofamid and peak area. A stock solution of cyazofamid $\left(100 \mu \mathrm{g} \mathrm{mL}^{-1}\right)$ was prepared while working solutions from 0.05 to $10.0 \mu \mathrm{g} \mathrm{mL}^{-1}$ were prepared by serial dilution of the stock solution with acetonitrile. The linearity of the HPLC assay and calibration curve was evaluated in triplicate at six concentration levels consisting of $0.1,0.5,1.0,2.0,5.0$ and $10.0 \mu \mathrm{g} \mathrm{mL}^{-1}$ cyazofamid.

\section{Data analysis}

The experimental data were subjected to analysis to determine standard deviation among the replicates. The amount of pesticide residues that remained at different intervals was fitted to first-order exponential decay equation

$C_{t}=C_{\mathrm{o}} \mathrm{e}^{-k t}$

where $C_{t}$-the concentration $\left(\mu \mathrm{g} \mathrm{g}^{-1}\right)$ after time, $t$ (day), $C_{\mathrm{o}}$-initial concentration $\left(\mu \mathrm{g} \mathrm{g}^{-1}\right), k$-rate constant $\left(\right.$ day $\left.^{-1}\right)$.

The half-life was computed using Eq. (2)

$t_{1 / 2}=[0.693 / k]$

where $k$ is rate constant in days.

\section{Results and discussion}

The physicochemical properties of the soils and soil composition showed that textures of soils were silty clay loam and sandy loam type (Tables 3, 4). Validation of the extraction procedure in terms of percent recovery the 
average values of recoveries of cyazofamid from both spiked soil samples ranged from 78 to $86 \%$. (Table 5)

The retention time of cyazofamid under the set conditions was found to be $7.6 \mathrm{~min}$. The chromatograms obtained showed no interfering peak at the retention time of the cyazofamid, i.e., at $7.6 \mathrm{~min}$ showing good specificity of the method. Detector response was linear to the concentration as the value of coefficient of determination $\left(R^{2}\right)$ was 0.999 giving good accuracy. The percent RSD was 1.72 showing good precision of the method. The limit of quantification for method and limit of detection for instrument were $0.05 \mu \mathrm{g} \mathrm{g}^{-1}$ and $0.01 \mu \mathrm{g} \mathrm{mL}^{-1}$, respectively.

\section{Dissipation in soils}

The amount of residue at different time interval estimated by HPLC is tabulated in Table 6 . The temperature and

Table 3 Physicochemical properties of soils of experimental field $(0-15 \mathrm{~cm})$

\begin{tabular}{lll}
\hline Parameters & Soil 1 & Soil 2 \\
\hline Particle size distribution & & \\
Sand (\%) & 9.80 & 50.07 \\
Silt (\%) & 60.20 & 31.85 \\
Clay (\%) & 30.00 & 18.08 \\
Texture class & Silty clay & Sandy loam \\
& loam & \\
Moisture content & $38.0 \pm 2$ & $32.5 \pm 2$ \\
Bulk density (mg $\left.{ }^{-3}\right)$ & $1.23 \pm 0.15$ & $1.07 \pm 0.10$ \\
pH & $7.06 \pm 0.1$ & $6.94 \pm 0.1$ \\
Organic carbon $(\%)$ & 1.2 & 0.75 \\
Electrical conductivity at $19{ }^{\circ} \mathrm{C}$ & $0.496 \pm 0.011$ & $0.451 \pm 0.012$ \\
$\quad\left(\mathrm{dS} \mathrm{m}^{-1}\right)$ & & \\
$\mathrm{Water} \mathrm{holding} \mathrm{capacity}(\%)_{\mathrm{CaCO}_{3}(\%)}$ & $151.95 \pm 1$ & $142.82 \pm 1$ \\
\hline
\end{tabular}

Soil 1 = silty clay loam; soil 2 = sandy loam
Table 5 Percent Recovery of Cyazofamid in Soil

\begin{tabular}{llllll}
\hline S. No & \multicolumn{2}{l}{ Silty clay loam } & & \multicolumn{2}{l}{ Sandy loam } \\
\cline { 2 - 3 } \cline { 5 - 6 } & $\begin{array}{l}\text { Amount } \\
\text { loaded } \\
(\mathrm{ppm})\end{array}$ & $\begin{array}{l}\text { Percent } \\
\text { recovery } \\
( \pm \text { SD })\end{array}$ & & $\begin{array}{l}\text { Amount } \\
\text { loaded } \\
(\mathrm{ppm})\end{array}$ & $\begin{array}{l}\text { Percent } \\
\text { recovery } \\
( \pm \text { SD })\end{array}$ \\
\hline 1 & 0.5 & $78.0 \pm 0.06$ & 0.5 & $80.6 \pm 0.04$ \\
2 & 2.0 & $82.6 \pm 0.02$ & & 2.0 & $83.0 \pm 0.05$ \\
3 & 5.0 & $86.0 \pm 0.02$ & & 5.0 & $85.5 \pm 0.01$ \\
\hline
\end{tabular}

Average of three replicates

relative humidity during the study period varied from 12 to $34{ }^{\circ} \mathrm{C}$ and 19 to $88 \%$, respectively (Table 2). Percent dissipation values at different time intervals were calculated considering the amount of fungicide recovered on 0th day ( $1 \mathrm{~h}$ after application) as $100 \%$. The persistence of cyazofamid in silty clay loam soil applied at $0.1 \mathrm{~kg} \mathrm{ha}^{-1}$ in soil decreased from 100 to $67.67 \%$ from 0th day ( $1 \mathrm{~h}$. after application) to 3rd day, and then, it gradually fell up to $36.11 \%$ till 7 th day, on 10th day of application, the persistence decreased to $19.44 \%$. In sandy loam soil application at $0.2 \mathrm{~kg}$ a.i. $\mathrm{kg} \mathrm{ha}^{-1}$, it degraded from zero percent to $12.50 \%$ from 0 th day $(1 \mathrm{~h}$. after application) to 1st day and then further degraded to $33.12 \%$ till 3rd day of application, on 7th day it further reduced to $63.12 \%$. Residues was below detectable limit $\left(<0.01 \mu \mathrm{g} \mathrm{g}^{-1}\right.$ soil) on 15 th day of application in both silty clay and sandy loam type of soils at both ( 0.1 and $0.2 \mathrm{~kg} \mathrm{ha}^{-1}$ ) treatments.

It is evident from Table 7 that residue of cyazofamid dissipates with almost the same rate in silty clay loam and sandy loam soil with almost same dissociation constant rate ( $k=0.13$ and 0.16 ) up to 10 days leaving no detectable residue on 15th day of application. Slight difference/almost same dissipation rate $(0.13$ and 0.16$)$ in both soils would be attributed to the fact that the $\mathrm{pH}$ of the soils was almost same beside high temperature also favoured in rapid degradation.

Table 4 Physicochemical properties of soils of experimental field depthwise

\begin{tabular}{|c|c|c|c|c|c|c|c|}
\hline \multirow{2}{*}{$\begin{array}{l}\text { Sl. } \\
\text { No. }\end{array}$} & \multirow[t]{2}{*}{ Properties } & \multicolumn{3}{|c|}{ Silty clay loam soil $(\mathrm{cm})$} & \multicolumn{3}{|c|}{ Sandy loam soil (cm) } \\
\hline & & $15-30$ & $30-45$ & $45-60$ & $15-30$ & $30-45$ & $45-60$ \\
\hline 1. & Sand $(\%)$ & 15.60 & 21.44 & 24.42 & 52.10 & 53.00 & 53.44 \\
\hline 2. & Silt $(\%)$ & 55.61 & 53.66 & 51.37 & 31.80 & 31.62 & 31.98 \\
\hline 3. & Clay $(\%)$ & 28.79 & 25.00 & 24.21 & 16.10 & 15.38 & 14.58 \\
\hline 4. & Organic carbon (\%) & 1.01 & 0.84 & 0.64 & 0.60 & 0.51 & 0.44 \\
\hline 5. & $\mathrm{pH}$ & $7.09 \pm 0.1$ & $6.46 \pm 0.1$ & $6.01 \pm 0.1$ & $7.01 \pm 0.1$ & $6.58 \pm 0.1$ & $6.14 \pm 0.1$ \\
\hline 6. & $\begin{array}{l}\text { Electric conductivity (1: } 2 \\
\left.\mathrm{~d} \mathrm{Sm}^{-1}\right)\end{array}$ & $0.304 \pm 0.011$ & $0.270 \pm 0.013$ & $0.126 \pm 0.012$ & $0.441 \pm 0.012$ & $0.445 \pm 0.011$ & $0.435 \pm 0.011$ \\
\hline 7. & $\mathrm{CaCO}_{3}(\%)$ & $0.497 \pm 0.06$ & $0.464 \pm 0.05$ & $0.298 \pm 0.08$ & $0.501 \pm 0.08$ & $0.488 \pm 0.07$ & $0.481 \pm 0.04$ \\
\hline
\end{tabular}


Table 6 Persistence of cyazofamid in soils

\begin{tabular}{|c|c|c|c|c|}
\hline \multicolumn{5}{|c|}{ Persistence $\left(\mu \mathrm{g} \mathrm{g}^{-1}\right) \pm \mathrm{SD}$} \\
\hline \multirow[t]{2}{*}{ Days } & \multicolumn{2}{|l|}{ Silty clay loam } & \multicolumn{2}{|l|}{ Sandy loam } \\
\hline & $100 \mathrm{~g}$ a.i. $\mathrm{ha}^{-1}$ & $200 \mathrm{~g}$ a.i. $\mathrm{ha}^{-1}$ & $100 \mathrm{~g}$ a.i. ha ${ }^{-1}$ & $200 \mathrm{~g}$ a.i. $\mathrm{ha}^{-1}$ \\
\hline 0 & $0.72 \pm 0.05$ & $1.25 \pm 0.07(100)$ & $0.82 \pm 0.03(100)$ & $1.60 \pm 0.06(100)$ \\
\hline 1 & $0.59 \pm 0.03(81.94)$ & $1.05 \pm 0.05(84.00)$ & $0.71 \pm 0.06(86.80)$ & $1.40 \pm 0.04(87.50)$ \\
\hline 3 & $0.48 \pm 0.05(67.67)$ & $0.85 \pm 0.02(68.00)$ & $0.53 \pm 0.05(65.62)$ & $1.07 \pm 0.06(67.07)$ \\
\hline 5 & $0.32 \pm 0.06(44.44)$ & $0.65 \pm 0.06(52.00)$ & $0.39 \pm 0.02(48.75)$ & $0.80 \pm 0.05(50.45)$ \\
\hline 7 & $0.26 \pm 0.02(36.11)$ & $0.40 \pm 0.01(32.00)$ & $0.29 \pm 0.03(35.36)$ & $0.59 \pm 0.07(37.40)$ \\
\hline 10 & $0.14 \pm 0.03(19.44)$ & $0.20 \pm 0.08(16.00)$ & $0.19 \pm 0.04(23.17)$ & $0.39 \pm 0.02(24.37)$ \\
\hline 15 & ND & ND & ND & ND \\
\hline
\end{tabular}

Values are mean of three readings

Values in parenthesis show percent persistence of fungicide

At the both application rates of cyazofamid, the values of logarithm of residue $(C)$ were plotted against time $(t)$ the distribution of points followed straight line pattern in both soils suggesting that dissipation of cyazofamid could occur through a single distinct phase conforming to first-order kinetics (Figs. 1, 2). The computed value of coefficient of determination $\left(R^{2}\right)$ for the degradation of cyazofamid in silty clay loam at both concentrations was 0.992 and 0.974 and in sandy loam was 0.999 which is statistically significant $(P=0.05)$. This signified that the kinetics of cyazofamid degradation rate followed monophasic first-order degradation kinetics in both soils.

The half-life $\left(t_{1 / 2}\right)$ value of cyazofamid calculated from the slope of the regression equation in silty clay loam at application dose 0.1 and $0.2 \mathrm{~kg}$ a.i. ha ${ }^{-1}$ was found to be 4.30 and 4.47 days while, for sandy loam soil, it was 4.74 and 4.98 days, respectively (Table 7).

Among the soils, irrespective of the factors, the dissipation of cyazofamid was more in silty clay loam than sandy loam soil. This may be due to high organic matter, high $\mathrm{pH}$ and moisture content of silty clay loam. Thus, the breakdown of cyazofamid appears to be soil dependent and reflects the number of organisms present in the soil capable of degrading the compound. Aerobic degradation of cyazofamid in soil occurs via hydrolysis to CCIM (4-chloro-5$p$-tolylimidazole-2-carbonitrile). This compound is further degraded to CCIM-AM (4-chloro-5-p-tolylimidazole-2carboxamide) and then to CTCA (4-chloro-5-p-tolylimidazole-2-carboxylic acid) (USEPA 2004). The half-life values are slightly higher in higher rate of application of cyazofamid in our study. This could be attributed to limitation in number of reaction sites in soil and toxic effects on microorganisms or enzyme inhibition.

The degradation of cyazofamid in soil depends upon soil texture, temperature and $\mathrm{pH}$. Under aerobic condition in different soils, its half-life ranges from 3.5 to 6.5
(USEPA 2004). Degradation studies of cyazofamid in soils showed that the first-order $\mathrm{DT}_{50}$ were found in the range of 3.8-15.1 days at $20{ }^{\circ} \mathrm{C}$ (Norwegian Food Safety Authority 2007). Dissipation studies conducted in Manitoba, Ontario and New York indicated rapid dissipation of cyazofamid, with $\mathrm{DT}_{50}$ ranging from 2.0 to 8.0 days. The rate of degradation increases with increase in $\mathrm{pH}$ of soil, and degradation rate was slower in loamy sand $\left(t_{1 / 2}=6.1-6.4\right.$ days, $\mathrm{pH}$ 6.5) than in sandy loam $\left(t_{1 / 2}=4.3-4.4\right.$ days, $\mathrm{pH} 6.9$ and 3.7-4.0, $\mathrm{pH}$ 7.6) and sandy soil $\left(t_{1 / 2}=4.9-6.0\right.$ days, $\left.\mathrm{pH} 5.9\right)$ (New York State Department of Environmental Conservation 2006). Dissipation of cyazofamid from turf was rapid (half-lives of 18-19 days). By 120 days after the last of three applications, $94-98.8 \%$ of the applied cyazofamid had degraded (primarily in the form of bound residues) (Wiedmann 2009). Cyazofamid persistence under field condition was less, half-life calculated was 4.5 days, and soil aerobic microbes played important role in degradation of fungicide (Suciu et al. 2011).

In our study, soil has high organic matter content, neutral $\mathrm{pH}$ and adequate moisture, which is necessary for the growth and development of microorganism and these factors plays major role for rapid degradation of fungicide. Other studies also confirm the fact that at high $\mathrm{pH}$ rate, degradation of cyazofamid was higher compared to low or acidic $\mathrm{pH}$. Organic matter and moisture content also play significant role as it harbors more aerobic organisms which is capable of degrading the compound. High temperature during the experimental period also favoured in rapid degradation. Environmental factors play important role in the degradation of pesticides. High temperature and humidity favor rapid degradation of pesticide in soil as these factors favor high microbial population and activity. In general, microbial activity increases in warm, moist and well-aerated soils, and rate of degradation decreases when there is low (temperature, 
Table 7 Dissipation kinetics of cyazofamid residues in soils

\begin{tabular}{|c|c|c|c|c|}
\hline \multirow[t]{2}{*}{ Properties } & \multicolumn{2}{|l|}{ Silty clay loam } & \multicolumn{2}{|l|}{ Sandy loam } \\
\hline & $100 \mathrm{~g} \mathrm{ha}^{-1}$ & $200 \mathrm{~g} \mathrm{ha}^{-1}$ & $100 \mathrm{~g} \mathrm{ha}^{-1}$ & $200 \mathrm{~g} \mathrm{ha}^{-1}$ \\
\hline$k\left(\right.$ days $\left.^{-1}\right)$ & $0.161 \pm 0.024$ & $0.155 \pm 0.025$ & $0.146 \pm 0.024$ & $0.139 \pm 0.006$ \\
\hline Half-life $t_{1 / 2}$ (days) & 4.30 & 4.47 & 4.74 & 4.95 \\
\hline$R^{2}$ & 0.992 & 0.974 & 0.999 & 0.998 \\
\hline Regression equation & $y=-0.071 x+0.122$ & $y=-0.077 x+0.130$ & $\mathrm{y}=-0.063 x+0.086$ & $y=-0.065 x+0.209$ \\
\hline
\end{tabular}

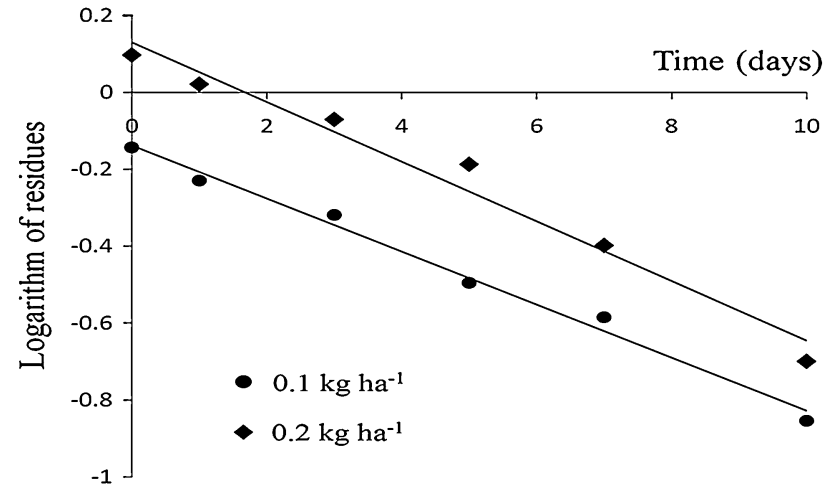

Fig. 1 Logarithm of cyazofamid residues in silty clay loam soil at two application dose

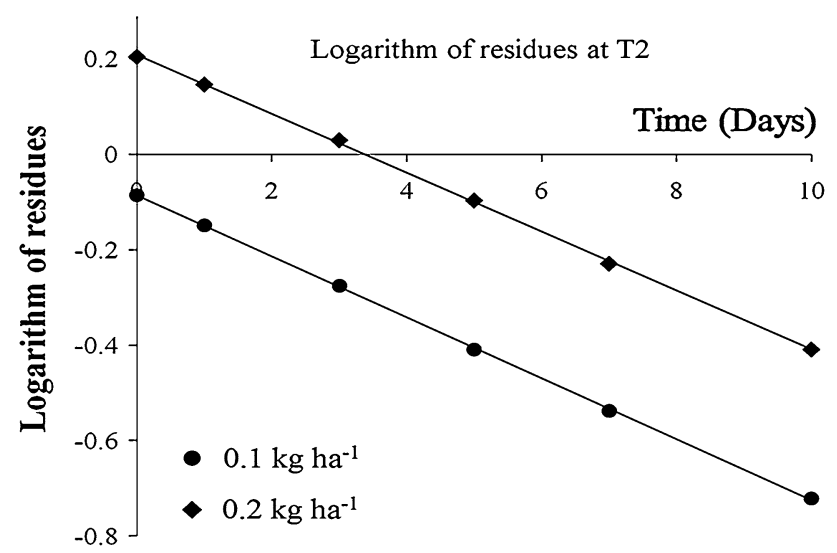

Fig. 2 Logarithm of cyazofamid residues in sandy loam soil at two application dose

moisture and aeration) in soil. (Matsumura 1989; Tiryaki and Temur 2010; Tandon et al. 2012a; b)

Dissipation was faster in silty clay loam compared to sandy loam, which would be attributed to the fact that silty clay loam soil is rich in organic carbon content; hence, more microbial activity would be in soil and microbes play significant role in degradation of fungicide. Beside this, it has higher percentage of clay; the fungicide is more adsorbed on its active sites and it will react with the molecule and would degrade (hydrolysis) or form bound residues.

\section{Leaching}

The residues of cyazofamid in different fractions of leachate for both soils which were collected from 1 to 5 days showed no residues in the leachates for both concentrations.

Distribution of fungicide residue in soils at different sections after passing 0.6 liter of water showed that the surface applied cyazofamid was not distributed equally throughout the whole column length but concentration varied at different soil depths. At both application doses, in silty clay loam soil, highest concentration was recorded in 5-10$\mathrm{cm}$ section, whereas in sandy loam soil, it was in $10-15-\mathrm{cm}$ section. No residue was found beneath $15-\mathrm{cm}$ layer of soils. Leaching of fungicide was more in sandy loam as compared to silty clay loam soil. Cyazofamid remains only in top soil, i.e., up to $15 \mathrm{~cm}$ length of column in both soils at both concentration doses showing its mobility to be very low in the soil columns (Table 8). This phenomenon might also be correlated with the amount of organic matter present in the soil (McLaughlin and Johnson 1997). It was evident that soil with sand facilitates more permeability and adsorption was relatively less which favored leaching. The presence of organic matter affects the movement of pesticide because of its high absorption capacity toward soil. Since sandy loam soil was deficient in organic matter, there was more movement of the fungicide as compared to silty clay loam soil. Leaching study reveals that mobility of surface applied cyazofamid was very less in both types of soils and show strong affinity for adsorption to soil.

After leaching and processing of the soil sample out of total 78.5 and $157.0 \mu \mathrm{g}$ cyazofamid added on both types of soil column, the recovery of cyazofamid in silty clay loam soil was $21.15 \mu \mathrm{g}(26.94 \%)$ and $41.72 \mu \mathrm{g}(26.57 \%)$ while recovery in sandy loam was $30.95 \mu \mathrm{g}(39.42 \%)$ and $59.38 \mu \mathrm{g}(37.82 \%)$, respectively. Loss of cyazofamid in silty clay laom soil was $57.35 \mu \mathrm{g}(73.06 \%)$ and $115.28 \mu \mathrm{g}$ $(73.43 \%)$, while in sandy loam soil, it was $47.55 \mu \mathrm{g}$ $(60.58 \%)$ and $97.62 \mu \mathrm{g}(62.18 \%)$ was observed. Low 
Table 8 The concentration of cyazofamid $\left(\mu \mathrm{g} \mathrm{g}^{-1}\right)$ in the different soil depth

\begin{tabular}{|c|c|c|c|c|}
\hline \multirow[t]{2}{*}{ Soil Depth $(\mathrm{cm})$} & \multirow{2}{*}{$\begin{array}{l}\text { Silty clay loam }\left(\mu \mathrm{g} \mathrm{g}^{-1}\right) \pm \mathrm{SD} \\
0.1 \mathrm{~kg} \mathrm{ha}^{-1}\end{array}$} & \multirow[b]{2}{*}{$0.2 \mathrm{~kg} \mathrm{ha}^{-1}$} & \multicolumn{2}{|c|}{ Sandy loam $\left(\mu \mathrm{g} \mathrm{g}^{-1}\right) \pm \mathrm{SD}$} \\
\hline & & & $0.1 \mathrm{~kg} \mathrm{ha}^{-1}$ & $0.2 \mathrm{~kg} \mathrm{ha}^{-1}$ \\
\hline $0-5$ & $0.751 \pm 0.031$ & $0.981 \pm 0.021$ & $0.684 \pm 0.026$ & $1.298 \pm 0.021$ \\
\hline $5-10$ & $0.960 \pm 0.024$ & $2.587 \pm 0.030$ & $1.049 \pm 0.022$ & $1.766 \pm 0.019$ \\
\hline $10-15$ & $0.404 \pm 0.023$ & $0.604 \pm 0.028$ & $1.165 \pm 0.018$ & $2.493 \pm 0.023$ \\
\hline $15-20$ & - & - & - & - \\
\hline $20-25$ & - & - & - & - \\
\hline $25-30$ & - & - & - & - \\
\hline $30-35$ & - & - & - & - \\
\hline $35-40$ & - & - & - & - \\
\hline $40-45$ & - & - & - & - \\
\hline $45-50$ & - & - & - & - \\
\hline $50-55$ & - & - & - & - \\
\hline $55-60$ & - & - & - & - \\
\hline
\end{tabular}

Values are mean of three readings

recovery of cyazofamid is due to the fact that it had halflife of 4.3-4.9 days in silty clay and sandy loam soils, beside other factors such as chemical hydrolysis, interaction among mineralization, formation of biotic and abiotic products viz., different metabolites as well as formation of bound residues also influenced in the low recovery of the fungicide.

Pesticide transport through the unsaturated/saturated zone is a function of chemical and soil characteristics, application and water recharge rate. Leaching studies done by other workers indicated that cyazofamid, and its metabolites had very low mobility in different soils and major residues and were confined to top $0-5 \mathrm{~cm}$ section of columns (Wiedmann 2009; Food Safety Commission 2004). Mobility of cyazofamid on four unaged different soils showed that more than $98 \%$ of the applied compound remained on the top $10 \mathrm{~cm}$ with very limited leaching and less than $1 \%$ of applied test material was present in the leachate (New York State Department of Environmental Conservation. 2006; Pest Management Regulatory Agency Canada 2006). Adsorption/desorption studies in four types of soil viz. US loamy sand, UK loamy sand, UK sandy loam and Germany sand, the Kf values indicate a medium to high degree of adsorption for the cyazofamid compound. The values of $\mathrm{Kf}$ and Koc varied from 4.6 to 65 and 736 to 2,172, respectively, indicating a high degree of adsorption (Norwegian Food Safety Authority 2007). A number of factors influences leaching of soil-applied pesticide, i.e., chemical nature of the pesticide compound, adsorption of pesticide to soil colloids, soil texture, soil permeability, volume of water flow, water solubility of pesticide, soil $\mathrm{pH}$ and inorganic and organic soil colloids (Anderson 1996). The result of our study indicates that cyazofamid is tightly adsorbed on the top layer of the soil, and hence, there is low movement of the fungicide. Suciu et al. (2011) also found that cyazofamid is strongly bound to the organoclays particles under laboratory conditions.

The results indicated that as silty clay loam soil was rich in organic carbon and had high clay content, this could be the reason for the higher retention of cyazofamid fungicide on the top soil compared to sandy loam soil in which more concentration was in deeper layers.

\section{Conclusion}

The fate of pesticide as well as its mobility in soil environment appears to be controlled by many biotic and abiotic factors. Degradation is dependent upon the chemical nature of the fungicide compound as well as the chemical and physical properties of the soil. The dissipation study of cyazofamid shows that it has first-order degradation kinetics in soil. Cyazofamid in silty clay loam soil and sandy loam has short half-life and does not persist for long period in soils indicating its short persistence. Under simulated rainfall condition, cyazofamid could not leached beneath $15 \mathrm{~cm}$ of soil depth in both types of soil. Strong affinity for adsorption to soil results in less hazards for environment as no possibility of groundwater contamination.

It could be concluded from the study that cyazofamid fungicide has short persistence in soils and leaves almost no residues, and hence, pesticide buildup in environment is negligible. There was very little movement of cyazofamid into the soil. It have high affinity for binding with the soil particles, and hence, there are remote chances of leaching through soil profile to pollute the groundwater. 
Acknowledgments Authors are thankful to M/s Ishihara Sangyo Kaisha (ISK) Biosciences Corporation, Japan (through United Phosphorus Ltd, India), for providing analytical cyazofamid for research purpose. Ms Nandita Singh is thankful to Indian Council of Agriculture Research (ICAR), New Delhi, India, for the financial support in the form of Junior Research Fellowship and also acknowledges the university authorities and the department staff for providing necessary help during the research work.

\section{References}

Anderson WP (1996) Weed science principles and applications, 3rd edn. West Publishing Company, St. Paul

Arora S (2006) Pesticides and environment in today's context. Agric Today 7:53-56

Choi JH, Abd El-Aty AM, Park YS, Cho SK, Shim JH (2007) The assessment of carbendazim, cyazofamid, diethofencarb and pyrimethanil residue levels in $P$. ginseng (C. A. Meeyer) by HPLC. Bull Korean Chem Soc 28(3):369-372

European Food Safety Authority (2012) Reasoned opinion on the review of the existing maximum residue levels (MRLs) for cyazofamid according to Article 12 of Regulation (EC) No 396/2005. EFSA J 10(12):3065-3103

Fischer R, Franz H, Hanel R, Siebers J (2003) Residue analysis of active substances from new plant protection products-10th communication: cyazofamid, propoxycarbazone, pyraclostrobin, silthiofam, spinosad. Nachrichtenblatt des Deutschen Pflanzensch- utzdienstes 55(9):189-197

Flury M (1996) Experimental evidence of transport of pesticide through field soils a review. J Environ Qual 25:25-45

Food Safety Commission (2004) Evaluation report, Cyazofamid. http://www.fsc.go.jp/english/evaluationreport/pesticide/ cyazofamid_fullreport.pdf. Accessed on 22 Dec 2011

Gomez KA, Gomez AA (1984) Statistical procedure for agricultural research. Wiley, NY

González-Rodríguez RM, Cancho-Grande B, Simal-Gándara J (2009) Multiresidue determination of 11 new fungicides in grapes and wines by liquid-liquid extraction/clean-up and programmable temperature vaporization injection with analyte protectants/gas chromatography/ion trap mass spectrometry. J Chromatogr A 1216(32):6033-6042

Hancock TC, Sandstrom MW, Vogel JR, Webb RMT, Bayless ER, Barbash JE (2008) Pesticide fate and transport throughout unsaturated zones in five agricultural settings, USA. J Environ Qual 37:1086-1100

Heimstra M, Kok AD (2007) Comprehensive multi-residue method for the target analysis of pesticides in crops using liquid chromatography-tandem mass spectrometry. J Chromatogr A 1154(1-2):3-25

Huang YL, Wu HM, Mao LJ, Zhang J, Zhu GN (2005) Determination of cyazofamid residues in cucumber and soil by high effective liquid phase chromatography. Acta Agric Zhejiangensis 17(1):19-22

Jackson ML (1973) Soil chemical analysis. Prentice Hall of India Pvt. Ltd., New Delhi

Kerle EA, Jenkins JJ, Vogue PA (2007) Understanding pesticide persistence and mobility for groundwater and surface water protection http://extension.oregonstate.edu/catalog/pdf/em/ em8561-e.pdf. Accessed on 29/2/2012

Lacina O, Urbanova J, Poustka J, Hajslova J (2010) Identification/ quantification of multiple pesticide residues in food plants by ultra-high-performance liquid chromatography-time-of-flight mass spectrometry. J Chromatogr A 1217(5):648-659
Laskowski DA, Swann RL, McCall PJ, Bidlock HD (1983) Soil degradation studies. Residue Rev 85:139-147

Lee H, Kim E, Moon JK, Zhu YZ, Do JAh, Oh JH, Kwon K, Lee YD, Kim JH (2012) Establishment of analytical method for cyazofamid residue in apple, mandarin, Korean cabbage, green pepper, potato and soybean. J Korean Soc Appl Biol Chem 55(2):241-247

Matsubayashi Y, Kato Y, Ogyu S (1995) Analytical procedure for the determination of IKF-916 in crops. Internal Report no. F-306. Ishihara Sangyo Kaisha, Ltd. Central Research Institute, Japan

Matsumura F (1989) Biotic Degradation of Pollutants. In: Bourdeau P, Haines JA, Klein W, Krishna Murti CR (eds) Ecotoxicology and climate. Wiley, New York, pp 79-89

McLaughlin RA, Johnson BS (1997) Optimizing recoveries of two chlorotriazine herbicide metabolites and 11 pesticides from aqueous samples using solid-phase extraction and gas chromatography-mass spectrometry. J Chromatogr A 790(1-2):161-167

Mitani S (2001) Ranman (Cyazofamid): a novel fungicide for the control of Oomycetes plant diseases. Agrochem Jpn 78:17-20

Mitani S, Araki S, Takii Y, Ohshima T, Matsuo N, Miyoshi H (2001a) The biochemical mode of action of the novel selective fungicide cyazofamid: specific inhibition of mitochondrial complex III in Phythium spinosum. Pestic Biochem Physiol 71(2):107-115

Mitani S, Araki S, Yamaguchi T, Takii Y, Ohshima T, Matsuo N (2001b) Antifungal activity of the novel fungicide cyazofamid against Phytophthora infestans and other plant pathogenic fungi in vitro. Pestic Biochem Physiol 70:92-93

Mitani S, Araki S, Yamaguchi T, Takii Y, Ohshima T, Matsuo N (2002) Biological properties of the novel fungicide cyazofamid against Phytophthora infestans on tomato and Pseudoperonospora cubensis on cucumber. Pest Manag Sci 58(2):139-145

New York State Department of Environmental Conservation (2006) Registration of Ranman 400SC (Cyazofamid). Division of solid \& hazardous material, Bureau of pesticide management. http:// www.dec.state.ny.us/website/dshm/pesticid/pesticid.htm. Accessed on $28 / 2 / 2012$

Norwegian Food Safety Authority (2007) Registration report, Ranman twinpack (cyazofamid). Norwegian Food Safety Authority, Pesticides Section, Norway. Accessed on 29/2/2012

Ohshima T, Komyoji T, Mitani S, Matsuo N, Nakajima T (2004) Development of a novel fungicide, cyazofamid. J Pestic Sci 29(2):136-138

Pang GF, Cao YZ, Zhang JJ, Fan CL, Liu YM, Li XM, Jia GQ, Li ZY, Shi YQ, Wu YP, Guo TT (2006a) a) Validation study on 660 pesticide residues in animal tissues by gel permeation chromatography cleanup/gas chromatography-mass spectrometry and liquid chromatography-tandem mass spectrometry. J Chromatogr A 1125(1):1-30

Pang GF, Liu YM, Fan CL, Zhang JJ, Cao YZ, Li XM, Li ZY, Wu YP, Guo TT (2006b) Simultaneous determination of 405 pesticide residues in grain by accelerated solvent extraction then gas chromatography-mass spectrometry or liquid chromatography-tandem mass spectrometry. Anal Bioanal Chem 384:1366-1408

Pest Management Regulatory Agency Canada (2006). Cyazofamid. http://vre2.upei.ca/govdocs/fedora/repository/govdocs\%3A850/ PDF/PDF. Accessed on 12/5/2014

Pihlstrom T, Blomkvist G, Friman P, Pagard U, Osterdahl BG (2007) Analysis of pesticide residues in fruit and vegetables with ethyl acetate extraction using gas and liquid chromatography with tandem mass spectrometric detection. Anal Bioanal Chem 389(6):1773-1789

Pizzutti IR, Kok AD, Hiemstra M, Wickert C, Prestes OD (2009) Method validation and comparison of acetonitrile and acetone extraction for the analysis of 169 pesticides in soya grain by 
liquid chromatography-tandem mass spectrometry. J Chromatogr A 1216(21):4539-4552

Rial OR, Cancho GB, Simal GJ (2003) Multiresidue method for fourteen fungicides in white grapes by liquid-liquid and solidphase extraction followed by liquid chromatography-diode array detection. J Chromatogr A 992(1-2):121-131

Suciu NA, Ferrari T, Ferrari F, Trevisan M, Capri E (2011) Pesticide removal from waste spray-tank water by organoclay adsorption after field application to vineyards. Environ Sci Pollut Res 18(8):1374-1383

Tandon S, Singh N (2012) Method development for determination of cyazofamid in soil and water by HPLC. J Liq Chromatogr Relat Technol 35(7):924-926

Tandon S, Pujari A, Sand NK (2012a) Dissipation studies of fentrazamide (YRC-2388) under anaerobic condition. J Environ Monit 14:2521-2526

Tandon S, Pujari A, Sand NK (2012b) Degradation of fentrazamide herbicide in soil under aerobic condition. Bull Environ Contam Toxicol 89(2):312-315

Tiryaki O, Temur C (2010) The fate of pesticide in the environment. J Biol Environ Sci 4(10):29-38

Tseng SuH, Liu CC, Lin YJ, Chen HC, Su SC, Chou HK, Chou SS, Chih-Shih DY (2009) Analysis of 81 pesticides and metabolite residues in fruits and vegetables by diatomaceous earth column extraction and LC/MS/MS determination. J Food Drug Anal 17(5):319-332
USEPA (2004) Pesticide fact sheet: cyazofamid. http://www.epa.gov/ opprd001/factsheets/cyazofamid.pdf (Accessed on 29/2/2012)

Webb RMT, Wieczorek ME, Nolan BT, Hancock TC, Sandstrom MW, Barbash JE, Bayless ER, Healy RW, Lindard JI (2008) Variations in pesticide leaching related to land use, pesticide properties, and unsaturated zone thickness. J Environ Qual 37(3): 1145-1157

Wiedmann JL (2009) Turfgrass dissipation of cyazofamid in: turf grass: pesticide exposure assessment and predictive modeling tools. ACS Symp Ser 1028:97-109

Xu C, Ding XL, Liu KY, Li ZY (2009) Analysis of cyazofamid Tc by HPLC. Agrochemicals 07:502-503

Yamaguchi I, Fujimura M (2005) Recent topics on action mechanisms of fungicides. J Pestic Sci 30(2):67-74

Zeng T, Ziegelgruber KL, Chin YP, Arnold WA (2011) Pesticide processing potential in prairie pothole porewaters. Environ Sci Technol 45:6814-6822

Zeng T, Chin YP, Arnold WA (2012) Potential for abiotic reduction of pesticides in prairie pothole porewaters. Environ Sci Technol 46:3177-3187

Zong HY, Lan LX, Hua LY, Ming WH, Nian ZG (2009) The photolysis of cyazofamid. J Agro-Environ Sci 01:151-155 